
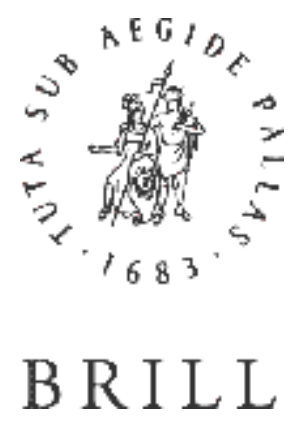

\title{
The Cohortes Augustae Cyrenaicae
}

\section{Author(s): Julian Bennett}

Source: Journal of African Archaeology, Vol. 7, No. 1 (2009), pp. 107-121

Published by: Brill

Stable URL: https://www.jstor.org/stable/43135471

Accessed: 24-07-2018 11:46 UTC

JSTOR is a not-for-profit service that helps scholars, researchers, and students discover, use, and build upon a wide range of content in a trusted digital archive. We use information technology and tools to increase productivity and facilitate new forms of scholarship. For more information about JSTOR, please contact support@jstor.org.

Your use of the JSTOR archive indicates your acceptance of the Terms \& Conditions of Use, available at https://about.jstor.org/terms 


\section{The Cohortes Augustae Cyrenaicae}

Julian Bennett

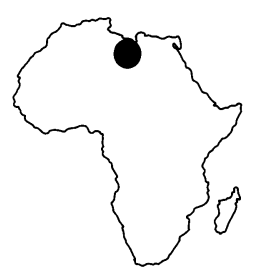

\section{Abstract}

The auxiliary regiments of the Imperial Roman army were as vital to the defensive and offensive capabilities of the Roman Empire as the better-known Roman legions. Initially raised on an ethnic basis through the levy from among Rome's subject peoples, and then maintained at or near their full strength by conscription and voluntary recruitment, these units of auxilia were often deployed far from their original 'home'. As such, by analysing where these units were recruited and in what numbers, and then studying their subsequent history and deployment, it is possible to begin an assessment of their full value to Rome and to better comprehend overall developments in Roman strategic thinking. This paper contributes to such an appraisal by reviewing the evidence for the history and deployment of the three cohortes Augustae Cyrenaicae, among the least well-known auxiliary units in the entire Roman army.
Résumé

L'Empire Romain dépendait tout autant, pour sa capacité à se défendre et attaquer, des régiments d'auxiliaires de l'armée Impériale que des légions qui sont mieux connues. Ces contingents $d$ 'auxilia furent constituées d'abord de troupes ethniquement homogènes recrutés parmi les divers peuples soumis à Rome et dont les effectifs étaient, par la suite, maintenus à un niveau plus ou moins maximum par voie de conscription ou d'engagement volontaire. Ils étaient souvent déployés loin de leur lieu d'origine. Ainsi, il est possible, en analysant l'origine et les niveaux d'effectifs de ces bataillons, ainsi que par l'étude de leur histoire et de leur déploiement ultérieurs, d'arriver à un début d'évaluation de leur importance pour Rome et à mieux comprendre le développement global de la pensée stratégique Romaine. Le présent article contribue à une telle évaluation par un examen des données de l'histoire et du déploiement de trois cohortes Augustae Cyrenaicae, qui comptent parmi les moins connues des détachements d'auxiliaires de l'armée Romaine.

Keywords: Roman auxiliary cohorts, auxiliary unit recruitment; auxiliary unit names; auxiliary unit deployment; auxiliary unit history

Julian Bennett $\widehat{\beta}$ bennett@bilkent.edu.tr

$凶$ Department of Archaeology, Bilkent University, 06800 Bilkent, Ankara, Turkey

DOI 10.3213/1612-1651-10127 Published online in May 2009 C Africa Magna Verlag, Frankfurt M. 


\section{For John Spaul}

\section{Introduction}

The Roman Empire relied extensively on its auxiliary units, the auxilia, for maintaining law and order within the provinces and as a supplementary force for defending those areas bordering territories potentially or actively hostile towards Rome's interests. With very few exceptions these auxiliary regiments were composed mainly of men enlisted from among the peoples tributary to Rome, although several units included volunteers of both peregrine and Roman citizenship status. Through analysis of where and when these units were initially established and in what numbers, and then studying their later history and dispositions, it is possible to learn indirectly something about changes in Roman foreign policy, and better understand developments in contemporary military thinking. As such, the auxiliary regiments raised from the territories that Rome controlled in North Africa are of especial interest. This is in part because many of the units enrolled there were seemingly created at an early date in the Imperial period, but more especially it is because in terms of their geographical extent, these territories contributed far less than their fair share - as it were - of such units. In fact the five provinces of Egypt, Cyrenaica (and Crete), Africa Proconsularis (with Numidia), and the Mauretanias, Caesariensis and Tingitana, supplied a mere 16 or so infantry units and some three cavalry squadrons out of the overall totals of roughly 315 infantry and 90 cavalry auxiliary formations known from epigraphic and other sources. The reasons for this have not yet been determined; but an explanation might be found from detailed forensic study, identifying when these units were initially raised, and where and when they were later deployed. Hence one purpose of this paper is to provide a preliminary contribution to such a study through examining the known information about the three auxiliary cohortes that were named for the region of Cyrenaica. Before going any further, however, it might be as well to briefly go over the nature of the Roman auxilia.

\section{The origins and structure of the Roman auxilia}

The first auxiliary formations employed by the Roman army were brought into existence on an ad-hoc basis during the Republican period for specific campaigns. By and large they were provided on a 'voluntary' basis by the cities and territories that were in a treaty relationship with Rome as socii et amici populi Romani, 'allies and friends of the Roman people'. This extemporized practice of enrolling such units certainly continued into the early $1^{\text {st }}$ century $\mathrm{AD}$, when some of Rome's allied states supplied what were to all intents and purposes auxilia for a campaign against Armenia in the AD 50's (Tacitus Annnales 13.8; $c f$. BENNETT 2006a: 83). However, epigraphic and other evidence reveals that long before then Augustus (28 BC-AD 14) transformed this customary method of enrolment by establishing permanent auxiliary units of 500 or so men in regiments of infantry, the cohortes peditatae, or of combined infantry and cavalry, the cohortes equitatae, and as squadrons of cavalry, the alae (HOLDER 1980: 5) The date as to when this reform was implemented is unclear, but it can be associated with the advice given in $29 \mathrm{BC}$ by Maecenas to Augustus (or Octavian, as he then was) that a permanent standing army should be established from 'the citizens, the subject nations [sc, the provinces], and the allies', the better to defend the imperium (Dio Historia 52.1.27). Even though we might suspect Dio's precise wording of the speech in question there is no need to think that the subject matter or the date of the discussion are inventions: after all, cohortes peditatae, cohortes equitatae, and alae certainly did exist under Augustus. At some later date, though, and evidently before $\mathrm{AD} 66$, a number of 'double-size' auxiliary units were also formed (BIRLEY 1966: 55 = BIRLEY 1988: 350; KENNEDY 1983). These were given the suffix milliaria to indicate their nominal complement of 1,000 men and distinguish them from any like-numbered and named formations of the usual 500-man type, such units usually being designated as quingenaria in modern works, although the label was rarely used in Roman times (HoLDER 1980: 6). From then on until the time of Trajan (AD 98-117), or possibly Hadrian (AD 117-139), when the unorthodox military formations known as national numeri first appeared (SOUTHERN 1989), the nature and the composition of Rome's auxiliary forces remained essentially constant.

Whether composed entirely of infantrymen, or part-mounted, or cavalry, most auxiliary units were first raised through the dilectus, a military levy conducted on a localised and territorial basis ( $c f$. BRUNT 1974 = BRUNT 1990: 188-214). Thus they were normally named in the genitive plural for the source of the founding complement, whether an ethnos, or urbanised community (civitas or polis), or a province or territory. Likewise if more than one unit was raised from the same source they were usually numbered in sequence for their origin, as with, for example, the cohors I Breucorum, raised from among the Breuci of the Balkan region, and its sister regiments, the cohors II Breucorum, the cohors III Breucorum, and so on. 
Either way, we might safely assume that each of these new regiments was based on a cadre of experienced officers and men transferred from existing formations, not the least because they were normally placed from the first under Roman citizen commanders.

On the other hand, it was not unknown for preexisting militias in the poleis of the Greek-speaking East to be transformed directly into auxiliary units after their home region was annexed by Rome. Augustus set a kind of precedent for this when he made Galatia a province in $25 \mathrm{BC}$, subsequently establishing a new legion, the legio XXII Deiotariana, around a core element of the existing Galatian royal army, and naming it for Deiotarus, the Galatian ruler who created this force around 50 BC (KEPPIE 1984: 141; cf. DARIs 2000 for its later history). The process involved in this case must have been relatively simple: the Galatian royal army was organised, equipped and trained in the exact manner of a Roman legion. Yet there can surely be no question that a cadre of experienced officers and lower ranks was transferred from other legions to help formally commission the new legio XXII Deiotariana.

Doubtless a like procedure was followed with those urban militias transformed into regular auxiliary units once their homeland was formally absorbed by Rome. Typical of such units were the ala Sebastena / Sebastenorum and the cohors I Sebastena / Sebastenorum; assuming, that is, that they were formalised as regular auxilia in AD 44, when Judaea was decisively annexed to Rome. For they may have been established at an earlier date, either when Judaea experienced its first term as a Roman province, or as a 'contribution' offered at the time Judaea held client status (SPEIDEL, M.P. 1982-1983: 233-234 = SPEIDEL, M.P. 1992: 224-232; also SpAUl 1994: 195-197 and 2000: 453). A more secure instance of the process, however, can be seen when Pontus Polemoniacus was attached to the province of Galatia-Cappadocia in AD 63/64 The local militia at Trapezus was then given Roman weapons and armour as well as Roman citizenship and reconstituted as a regular auxiliary cohort ( $c f$. BENNETT 2006a: 86). Indeed, at a later date Hadrian may well have done something similar in Thrace, given that the cohors I Aelia Athoitorum was quite possibly created from an existing militia in that province (HOLDER 1998: 253-254).

In their early years at least, and whether raised entirely de novo or through changing the status of existing militias, most if not all of the newly-formed auxiliary regiments seem to have been maintained at strength with fresh recruits taken from the same named place of origin. Consider as an example the cohortes VII and VIII Breucorum, units first set up during the Neronian or early Flavian period (AD 54-81) and deployed in Germania shortly after their creation, which continued to take in new recruits from that region for some time thereafter ( $c f$. SPaUl 2000: 325-327). Over time, though, the primary ethnic quota in any auxiliary unit was inevitably gradually diluted. This was a natural result from the way the auxilia began to be positioned in places far distant from their 'home' region, and so increasingly began to rely on recruits from where they were based rather than from their 'origin'. This explains why, to give just one example, a native of Cyrrhus in Syria was discharged from the 'Moorish' cohors I Musulamiorum sometime after its transfer from Syria to Lycia-Pamphylia (SPAUl 2000: 472; also BENNETT 2007: 140-141). Yet while local recruitment probably accounted for the way in which most auxiliary units were kept at full strength, in times of crisis it was not unknown for a unit to receive a body of newly enlisted recruits from another region entirely and so radically alter its ostensible ethnic complement. Consider, for example, the cohors I Augusta Lusitanorum. Originally raised in modern Portugal, it was deployed to Egypt sometime before $\mathrm{AD} 117$, in which year it received 120 recruits from the province of Asia. This number represents at least $28 \%$ of the unit's paper strength, and so given the year the new recruits were most likely drafted to replace battle losses incurred during the Second Jewish Rebellion (FINK 1971: 277-280, no. 74). However, while most auxiliary regiments were kept at strength through local recruitment or through block transfers, there are exceptions that test this fundamental rule, as with the cohors I Hemensenorum sagittaria (SPAUL 2000: 411-414). This regiment of archers was originally constituted as a quingenary unit in the late $2^{\text {nd }}$ century at Emessa (Homs) in Syria, but soon after and certainly by AD 199-202 - it was elevated to milliary status (SPAUL 2000: 411). From the time it was first established it was apparently permanently attached to the garrison of Pannonia Inferior but it clearly received fresh recruits from Emessa itself and from other parts of Syria at various times long after being deployed to the middle reaches of the River Danube (FITZ 1972).

All in all, though, it is clear that most auxiliary recruits saw service far away from their individual place of origin and in 'foreign' regiments that had long since left their own original recruitment area, such men often not even returning to their homes on discharge (e.g., PfERdeHIRT 2002: 244-245, with Karte 5). Even so, despite this progressive dilution of their original ethnic identity, a sense of pride and tradition (or simple reluctance to change?) saw all of Rome's auxiliary units retaining their original national name into at least the later $3^{\text {rd }}$ century. This is what allows scholars of the Roman army to trace where (and often 
when) they were initially raised and where they were deployed during the Early and High Roman Empire, a process that is considerably helped thanks to those epigraphic documents known as diplomata. The term diploma is itself a modern one, and is used for those bronze 'booklets' representing the officially certified copies of imperial constitutions listing those auxiliary men eligible for discharge after 25 years or more of military service, and who were then awarded Roman citizenship, the rights to a legal marriage, and (until AD 140) the extension of Roman citizenship to any of their children born before their discharge. More to the point, however, in addition to naming the individual recipient and his own regiment, the diplomata list inter alia all those auxiliary regiments in the relevant province that had men ready for release on the same date.

As such, then, diplomata provide a 'snapshot' of the auxiliary garrison in a province on the date of issue, and also allow us to trace the movements of individual units over time. In addition they allow us to suggest a possible terminus ante quem for a particular unit's initial creation as all those regiments listed on a diploma should have, in theory, been in existence at least 25 years earlier. However, this point should not be pressed: the inclusion of a regiment on a diploma indicates only that it had men who had completed 25 years service on the date it was issued and not necessarily that the unit itself had already been in existence for that time. This is so because almost all new auxiliary units were formed around a cadre of experienced soldiers sent from other units and because experienced auxiliary men are known to have transferred from one unit to another in the course of their service. An inscription from Galatia demonstrates the latter point. It records how the man named thereon had initially been recruited as an infantryman into the Cohors I Montanorum (equitata?), before later transferring as a cavalryman into the ala Atectorigiana (BENNETT, forthcoming). In other words he had already completed some years of service before being discharged from his final posting, the point being that the earliest mention of a unit on a diploma should not automatically be taken as indicating that the unit concerned had been formed at least 25 years earlier.

Needless to say, diplomata play their own significant part in allowing us to trace the history of the three cohortes Augustae Cyrenaicae, the focus of this paper, even though each of these units has left very few epigraphic records for their existence ( $c f$. Spaul 2000: 386-388). In fact two of these cohortes are only recorded on one and the same diploma. However, before embarking on this voyage of discovery, it is necessary to examine how these three units acquired the two elements in their official title. Not only does this represent a quite unusual and very distinctive exception to the way in which auxiliary units were usually labelled, but it is also crucial in determining when and where they were originally raised.

\section{The epithet Cyrenaica}

We must first examine the rationale for the second name, Cyrenaica, shared by the three cohortes under consideration. As noted above, auxiliary units were normally named in the genitive plural for the place that supplied the initial complement. Thus a unit formed from among the peoples of Cyrenaica would be expected to have Cyrenaeorum in its title and not Cyrenaica, the adjectival form of the territorial name. Indeed, CheEsman (1914: 47) stated in his seminal work on the Roman auxilia that nomenclature of this type should on the whole be taken to signify a unit that had served within the named territory rather than one raised from it, the adjectival form of a provincial name being taken in a secondary place in a unit's title to distinguish it from any namesake when two like-titled regiments were serving together on an expedition or in the same province. Hence the cohors II Hispanorum Cyrenaica (SPAUl 2000: 129-130), or the 'cohors II Hispanorum that was stationed in Cyrenaica', was so called to mark it out from the other four or so cohortes also designated cohors II Hispanorum; similarly the cohors I Lusitanorum Cyrenaica (cf. SPAUL 2000: 61-62), was given its distinctive cognomen to distinguish it from its otherwise identical namesake. Yet CHEESMAN (1914: 62, n.6) also noted, in explicit reference to these Cyrenaean units, how there were clearly occasions when a newly raised unit took the adjectival version of a provincial or territorial name in place of the right and proper form. Unfortunately he failed to spell out his reasoning as to why this might be so, and any possible elaboration ended with his death in the First World War. However, we may take it that what he meant was that if the adjectival from of a territorial name is the only or usual version registered for a particular unit, then it is likely that that unit was first raised in the region it was named for (cf. HOLDER 1980: 19-21).

KENNEDY (1977: 253-254) has challenged this view on why some units took the adjectival form of a territorial name to indicate their place of origin. He forcefully stated that the Cyrenaean units were so-called simply because they had been stationed in that territory. Indeed, he suggested that the Cyrenaean regiments might have at first been known as the cohortes I-III Augustae and that they acquired their adjectival cognomen on being deployed elsewhere after initial service in Cyrenaica, although HOLDER (1980: 20-21) has established that 
it is highly unlikely that any auxiliary units were ever known by an imperial title alone. More to the point, what Kennedy overlooked was what CHEESMAN (1914: 62, n. 6) had recognised: that the situation regarding these three consecutively numbered Cyrenaean units does not compare with most units that have an adjectival territorial name in their title, for these include it as the secondary element to a more usual genitive plural form. In other words, in the case of the Cyrenaean units it might be assumed that the adjectival use of a generic geographical name to denote their primary origin was seen as being somehow equivalent to the normal practice of having a title in the genitive plural. As it is, M.P. SPEIDEL (1976 = SPEIDEL, M.P. 1984: 91-100) demonstrated how this was true for the four units Augustus formed using citizen volunteers(?) from Italy, being the cohors Apula, created before AD 6 and named for the region of Apulia (SPAUL 2000: 21), the cohors I Campana (ibid.: 22-23), and cohortes I and II Italicae (ibid.: 26-27 and 29), which were established with men from respectively Campania and from Italy as a whole. In addition, this also seems to be the case with the four other peregrine auxiliary units regularly named in adjectival fashion: the ala veterana Gallica (SPAUL 1994: 126-129), the cohors I Bosporiana (ibid: 343), the cohors IV Cypria (ibid.: 389), and the cohors I Gallica (ibid.: 153-154).

All in all, it would seem that there are two possible explanations for why a unit took a territorial name in adjectival form as their primary title. It could be that some if not all of them were first constituted from a levy covering a large province or territory with more than one primary named ethnic tribe or urbanised centre. In other words, it may have been the case that just as the cohors I Italica was raised with men drawn from several regions in Italy, the Cyrenaean cohortes were raised through a dilectus from all of Cyrenaica, which in addition to its Hellenised urban centres contained at least six named local tribes (Pliny Naturalis Historia 5.5: cf. Ptolemy Geographia 4.4, for a slightly different list). In fact an explanation along these lines finds some support in the way that certain other peregrine auxiliary units took on a provincial or territorial name rather than that of a single ethnos or polis/civitas. Consider for example those units titled as Hispani and Galli, which, as CHEESMAN (1914: 58) stressed, were evidently drawn from the more 'civilised' regions of the Roman Empire, in this case the provinces of Tarraconensis and Lugdunensis respectively, as opposed to those auxiliary formations with specific tribal designations, like the Vardulli and Batavi, recruited from the less 'civilised' regions of northern Hispania and of Belgica. It could be, then, that the cohortes Cyrenaicae were so named because they were first constituted using recruits drawn from the 'civilised' poleis and ethne of Cyrenaica. However, while en-bloc enrolment from a number of 'civilised' peoples within one territory might well explain the anomalous naming in the adjectival territorial form of these Cyrenaean and several other 'regional' regiments, it would clearly not apply to the cohors $I$ Bosporiana or the cohors IV Cypria. Therefore we must concede that at least one other factor must apply, the most obvious one being that all of these units were formed before the naming of units in the genitive plural had become the norm. This indeed could well explain why the cohors I Belgarum (SPAUL 2000: 190-192) is recorded as the cohors I Belgica on at least one early inscription (CIL 13.7038), instead of in the normal genitive plural. Either way, there is no doubt as to the Augustan foundation date for the four Italian units that were titled in adjectival form, the cohors Apula, the cohors Campana, and the two cohortes Italicae (cf. SPEIDEL, M.P. 1976).

Yet whatever the explanation may be for why some auxiliary units were named in adjectival form after a territory, the fact remains that we have three cohortes named Cyrenaica rather than Cyrenaeorum, and that, as was the case with the cohortes I-III Gallicae, they were evidently raised in consecutive order. Special pleading would certainly be required to explain the inclusion of a territorial name in the title of these units in any other way other than that they were raised in their respective territories in respective order at more or less the same time.

\section{The epithet Augusta}

As if finding a clear explanation for the adjectival form of the territorial name as used in the title of the Cyrenaean (and other) regiments was not problematical enough, we face like difficulties in clarifying how they acquired the first element, Augusta. It is a so-called 'Kaiserbeiname', that is an additional name derived from an imperial nomen, in this case Augustus, but as was the case with other units with 'Kaiserbeinamen', it is often omitted from the relevant epigraphic texts. The reason why the name of some Roman auxiliary units was so apparently carelessly or haphazardly recorded is not exactly clear, although a possible explanation is forthcoming in the way these 'variations on a theme' are found in the surviving epigraphic record. That is to say, an official text, such as a diploma or a dedication stone on a building constructed by the unit, is more likely to report its full formal title than any private text, such as a tombstone, wherein the unit's name might not only be abbreviated, but might even omit some of its constituent elements, presumably to fit the minimum 
essential information on the text concerned. Thus as we will see, the cohors I Augusta Cyrenaica is listed as such on a diploma for Cappadocia of $\mathrm{AD} 101$, but is named without the title Augusta on a funerary text from the mid- $1^{\text {st }}$ century $\mathrm{AD}$ and also on an altar that can be intrinsically dated precisely to AD 212-218. Still, just to confuse the issue, the full title of this same unit is found on two funerary monuments of a probable late $2^{\text {nd }}$ or early $3^{\text {rd }}$ century date. More to the point, even where official documents are concerned, there was evidently no hard-and-fast rule on how the name of a specific auxiliary unit was to be presented: for example, the cohors II Augusta Cyrenaica is named thus on a diploma of AD 74, but is listed without the Augusta on diplomata of AD 90 (see below).

Whatever the reasons are why the title Augusta is present on some documents and absent from others recording these three Cyrenaean regiments, the rationale behind its inclusion in their shared title needs to be investigated. The opinio communis is that the presence of a 'Kaiserbeiname' in a primary position in a unit's title generally testifies that the emperor in question was specifically responsible for its creation. This certainly seems to have been the case with the majority of those alae and cohortes named Flavia for one or other of the Flavian emperors, most likely Vespasian (AD 69-79: HoLDER 1980: 16-18), and those that have Ulpia for Trajan (AD 98-117: ibid.: 18), or Aelia for Hadrian (AD 117-138: HoldER 1998) - but as HoldER (1980: 14-15) reminds us, there are clear exceptions that test this rule and especially so with those named Augusta. Nonetheless, some deductions are possible, as with the specific case of the cavalry regiment known in full as the ala Augusta ob virtutem appellata, that is to say, the 'ala named Augusta because of its bravery'. So in this case a unit awarded the title Augusta as a specific mark of valour and honour (cf. ibid.: 14-15; SPAUL 1994: 55-57). This specific indication as to how the ala Augusta ob virtutem appellata won its title is, unfortunately, unique. But another example of this procedure is perhaps to be found in the case of the ala I Flavia Britannica milliaria civium Romanorum: it is sometimes named in the epigraphic record as the I Flavia Augusta Britannica milliaria civium Romanorum (cf. SPAUL 1994: 68-71), and it too might have won the right to the title Augusta for valour.

On the other hand, the acquisition of the appellation Augusta 'honoris causa' seems most unlikely to be the case with these three Cyrenaean regiments - or, indeed, their ostensibly 'sister' units, the three cohortes Augustae Thracum. This is because they are the only auxiliary units raised in a series of three with Augusta as the primary element in their formal title and a specific territorial designation as the second. Thus it is reasonable to conclude that each group of three was raised in quick succession, in each case probably as the result of a single enlistment programme, presumably under Augustus himself, from among the peoples in the region they were named for. Having said that, it might naturally be objected that this seems unlikely to have been so with regard to the Thracian cohortes Augustae. Thrace did not become a province until Claudius (AD 41-54) formally annexed it to the Roman imperium in AD 45 (cf. BECHERT 1999: 177-180), and so a Claudian date might be thought more apt for the creation of any Thracian cohortes. On the other hand these units (along with the like-named alae) may have been formed from those Thracians serving in Herod's army at the time Augustus initially annexed Judaea as a province ( $c f$. HoLDER 1980: 14; also Josephus Antiquities 17.198). Alternatively, it could be that these units were constituted by levy or as a gift while Thrace was still a client state and before the territory was formally appropriated under Claudius. After all, Roman action against rebellious tribes in Thrace under Augustus, in $c a 15 / 14 \mathrm{BC}$ may well have encouraged the initial foundation of these units, either with volunteers loyal to Rome, or by enforced conscription as a form of punishment. To which we might add that even after Augustus' provincial reforms, some auxiliary regiments were constituted from among the socii et amici, those free territories allied to Rome. That is to say, a land did not have to be a province to contribute towards the establishment of new auxiliary regiments: the cohors $I$ Bosporanorum makes the point, as a unit raised in the Crimean Bosporus (SPAUL 2000: 343), a territory that was never formally annexed by Rome. So an Augustan timeframe for the initial establishment of these three Thracian cohortes Augustae is at the very least possible, and so also the way in which they took their name in honour of the first princeps.

Cyrene, on the other hand, had become a Roman possession in $74 \mathrm{BC}$, and was formally fused into a joint province with Cyprus from at least the time of Augustus' provincial reorganisation in 28/27 BC ( $c f$. BECHERT 1999: 103-106). However, this narrow strip of greenery, peace, and prosperity was bordered on the south by occasionally troublesome nomads, which is why sometime around 14 BC P. Sulpicius Quirinus, then presumably the governor of the province, led a successful expedition against one of those tribes, the Marmaridae; he was even offered - and surprisingly refused - the honorific name Marmaricus to celebrate his success (GRUEN 1996: 167-168). It could well be that Quirinus initially raised these three Cyrenean cohortes on behalf of Augustus precisely for his campaign against the Marmaridae or for providing security 
against any future attack by them or other inland tribes. After all, it might not be entirely due to the long arm of coincidence that at a later date we find two of the Cyrenaean cohortes in southern Asia Minor, which is where Quirinus led a hard-fought campaign against the Homonadeis of Isuaria sometime between (probably) 6 BC and AD 4 (Levick 1967: 202-214). Moreover, it might again not be simply by chance that the evidence, such as it is, indicates that in the Julio-Claudian - Flavian period (AD 14-96) Cyrene was garrisoned by two auxiliary units, namely the cohors II Hispanorum equitata (SPAUL 2000: 129-130) and the cohors I Lusitanorum (ibid.: 59-60), both adopting the cognomen Cyrenaica when later deployed elsewhere to denote their previous service in the province. The point being that in the relevant timeframe, a standing garrison of two cohortes was evidently considered sufficient for the defence and maintenance of order in Cyrenaica. Thus, they could well have been deployed there after the three cohortes Augustae Cyrenaicae who initially served this function under Quirinus were transferred for service elsewhere.

So far then, in view of the limited evidence to hand, we can with good reason refer back to the opinio communis and assign the formation of the three Cyrenaean (and likewise the three Thracian) cohortes to the Augustan period. Yet we must allow for the possibility that the Cyrenaean cohortes (and the Thracian cohortes as well) were raised by one of Augustus' successors who then fell from favour and suffered the procedure of damnatio memoriae. This was a process that involved the name of the condemned emperor being officially expunged and obliterated from the collective memory. It has been conjectured that in such cases that emperor's name would also be removed from the titulature of any auxiliary units that had incorporated this to be replaced with the neutral term 'Augusta' (SPAUL 2000: 506). This certainly seems to have been the case with certain regiments raised or honoured by Domitian once his memory was proscribed ( $c f$. HOLDER 1980: 15). There is, however, nothing to support the idea that this may have been the case with our three Cyrenaean regiments. Domitian is not known to have raised any auxiliary units from the east nor to have raised as many as three consecutively numbered units from one and the same territory (ibid.: 16-18). If the Cyrenaean units were re-named Augusta after an emperor who suffered damnatio memoriae, he would have had to be either Gaius-Caligula (AD 37-41) or Nero (AD 54-68). In fact it just happens that there is a literary reference to a dilectus in Cyrenaica under Nero (Tacitus Annales 14.18), but there is no evidence as to whether this was for auxiliaries or legionaries, and as such, we can go no further with this line of enquiry.
When all is said and done, then, we must concede that no precise explanation can be offered as to why the name Augusta occurs in the title of these three Cyrenaean units, although we can assuredly claim that they were indeed raised in the region they are named for ( $c f$. HOLDER 1980: 20). Even so, the balance of probabilities, and the evidence that suggests how two of them were likely to have been deployed in Asia Minor under Augustus (as will be seen), makes it highly probable that they were indeed formed during his reign. That being so, perhaps they were indeed initially formed in or around $14 \mathrm{BC}$ during a province-wide dilectus that was brought on by the campaign that Quirinus led against the revolting Marmaridae.

Having thus set out what can be deduced of the geographical and chronological origins of the cohortes Augustae Cyrenaicae, it behoves us to examine now the data for each of these units more closely on their own individual basis.

\section{The cohors I Augusta Cyrenaica}

The earliest dateable reference to the cohors I Cyrenaica (sic) may perhaps be found on a now-lost funerary monument from Mogontiacum (Mainz) set up in honour of C.Antestius Severus, a former praefectus (commander) of the unit (CIL 13.6812: $c f$. DeviJVER 1976: 103, A 125). We need to stress the 'perhaps' here, as DEVIJVER (1976: 103) thought the reading of the numeral ' $T$ ' on the text itself was not at all certain, and that the inscription named the cohors II Augusta Cyrenaica. It may have been that when evaluating the text he was inadvertently influenced by the knowledge that the cohors II Augusta Cyrenaica did serve in Germania whereas the cohors I Augusta Cyrenaica never did - as far as it is known. However, as we will see, Severus' command of his Cyrenaean unit was followed by a legionary tribunate in Germania, and it was very unusual for an equestrian to serve consecutive stages of his military career in the same province. Therefore, as Devijver occasionally - and quite understandably did make sporadic errors in reporting the inscriptions he reviewed for his magnus opus, we should stand by the original publication of this text and accept that it named the cohors I (Augusta) Cyrenaica.

That matter clarified, the inscription tells us how Severus first commanded an otherwise quite unknown cohors I or II Biturigum, then assumed charge of the cohors I Cyrenaica, before being appointed tribune in the legio IIII Macedonica. DEVIJVER (1976: 103) held that Severus' career should be dated to the Trajanic era, but the late Julio-Claudian or very early Flavian 
period (i.e., ca AD 54-80) seems more appropriate from the way that the inscription gives the full formal nomenclature of the deceased, including filiation and tribus. Besides, a military career involving successive commands of a cohors and then an ala before the legionary tribunate would better suit the later JulioClaudian period. It was not until the time of the emperor Vespasian that the equestrian tres militae was firmly set in its pattern of prefecture of a cohors, followed by a legionary tribunate, followed by the prefecture of an ala (DeViJVer 1973: 550 = DeviJVer 1989: 57). More conclusively, however, the legio IIII Macedonica was disbanded for one or other reason between AD 68-70, a cadre of its former complement becoming the nucleus of the newly enrolled legio IIII Flavia Felix (GóMEZPANTOJa 2000: 114-115). Therefore Severus' auxiliary prefectures and his command of the cohors I Augusta Cyrenaica must belong to a period before then.

The Mogontiacum inscription aside, the earliest secure mention of the cohors I Augusta Cyrenaica (sic) is to be found on a diploma issued on 29-iii-101 for the joint province of Galatia-Cappadocia ( $c f$. PFERDEHIRT 2004: 18, n. 1, for a transcript of this unpublished document; also SPEIDEL, M.A. 2007). However, some 16 years after this diploma was certified and issued, Hadrian dissolved that combined province to re-form the two separate provinces of Galatia and Cappadocia, and the evidence suggests that from then on, if not before, the cohors I Augusta Cyrenaica was a part of the garrison of Galatia. Such evidence comes in two forms. The first is that the regiment is not included in the listing of Cappadocian units presented in the Ektaxis kat'Alanon, a military situation report written ca $\mathrm{AD}$ 135 as a literary conceit by Flavius Arrianus, then governor of Cappadocia, to describe a successful excursus he had led against the Caucasian Alans (DEVoто 1993: 105-120). True, the Ektaxis kat'Alanon does refer three times to a unit of Cyrenaeans in the campaign (Arrian Ektaxis 1, 14 and 18), but as we will see, this can be identified without question as the cohors III Augusta Cyrenaica. Thus a natural conclusion for the absence of the cohors I Augusta Cyrenaica from this document is that it was not in Cappadocia at the relevant date, although it could be that the regiment was there and did not participate in this specific adventure. After all, Arrianus is unlikely to have used all of his auxilia for the excursus against the Alans, as that would have meant effectively leaving Cappadocia without a garrison.

Fortunately, this argument ex silentio, as it were, for positioning the cohors I Augusta Cyrenaica in Galatia in the Hadrianic period does find some support from the second set of evidence relevant to this matter, namely four inscriptions from that province revealing how by the later $2^{\text {nd }}$ and early $3^{\text {rd }}$ century, the cohors I Augusta Cyrenaica was most certainly there. The point is that by the time of Hadrian, the great majority of auxiliary units had become more-or-less static garrisons, in the sense that they moved from their allotted province only when deployed on a supra-regional campaign, after which they normally returned to their original station (SPAUL 1994: 268; $c f$. also the provincial listings given by HOLDER 2003, 121-144). So if the cohors I Augusta Cyrenaica was in Galatia in the late $2^{\text {nd }}$ century, it is more than likely to have been there from at least $c a \mathrm{AD} 117$, when Hadrian dissolved the joint province of Galatia-Cappadocia.

One of the inscriptions relevant to this matter comes from Pisidian Antioch, and is an acephalous Greek-language funerary monument to a man whose last name is preserved as Asclepios (BYRNE \& LABARRE 2006: 47-49 no. 85). As this element only of his name remains it is not clear if he held Roman citizenship or if he was of peregrine status. The text reports that he was

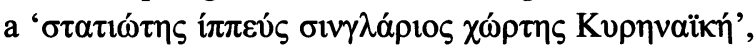
'cavalryman (and) singularis of the cohors Cyrenai$c a$ '. The absence of any numeral preceding the unit's title shows there was only one cohort of that name in the province at that date, and so, on the basis of the other texts to be reported here, it must be the cohors I Cyrenaica. As for the title of singularis associated with this man, this was given to those men who served in a mounted bodyguard, usually that supplied to a provincial governor (SPEIDEL, M.P. 1978: 17-22). Clearly Asclepius was most likely at Pisidian Antioch in such a capacity, for the man who set up the monument, another Asclepios, is described on the text as a

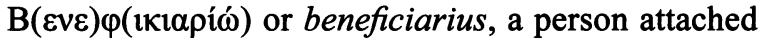
to a governor's administrative office. This Asclepios

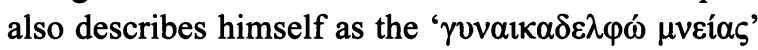
or 'brother-in-law' of the deceased, a terminology that might mean no more than that they were 'brothers in arms' rather than that they were actual brothers ( $c f$. FinK 1971: 349). On the other hand, the editors of this inscription have observed that such rare terminology is paralleled in Galatia by funerary memorials with christograms at the head of the text, from which they have assumed that the Pisidian Antioch inscription is of $4^{\text {th }}$ century date (BYRNE \& LABARRE 2006: 49, with n. 114). However, with the exception of this unusual phrasing, the overall formula of the Pisidian Antioch inscription conforms to the characteristic pattern of local $2^{\text {nd }}$ and $3^{\text {rd }}$ century funerary texts and could quite easily belong to an earlier period. This possibility is in fact strengthened to an extent in the way that the

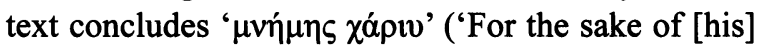
memory'), for Mrrchell (1993: 59) has observed that such a formula is found on Christian memorials of the 
period between $c a$ AD 200-260. Thus apart from the strong chance that our Asclepios may well have been a secret Christian, we might reasonably contend that he lived and died in the late $2^{\text {nd }}$ or early $3^{\text {rd }}$ century rather than in the $4^{\text {th }}$ century.

Two Greek-language inscriptions from Ancyra also record the deaths while in service of members of the cohors I Augusta Cyrenaica, and in both cases give the unit's full formal title. The first of these texts (SEG 6.32 = AE 1930.107 = BosCH 1967: 136, no. 113 = FRENCH 2003: 163, no. 54) gives the name of

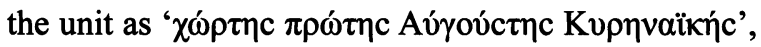
thus 'cohors prima Augusta Cyrenaica', and honours two men who are also described as 'brothers', but in this case with no preceding terminology, indicating that they are purely and simply 'brothers in arms' ( $c f$. FINK 1971: 349). The first man named on the stone was Quintus, the son of Philippikos, a native of Savatra in Lycaonia (Yağlibayat, Turkey). The way in which he is identified, name, filiation, and origo, shows that he was of peregrine status (MANN 2002: 230). Thus he most probably died before the Constitutio Antoniniana was issued in $\mathrm{AD} 212$, as this extended Roman citizenship to all freeborn men of peregrine origin - which is why large numbers of soldiers of a later date bear the nomen Aurelius in honour of the rescript's author, Marcus Aurelius Antoninus (better known as Caracalla: AD 211-217). At the time of his death, after 21 years serv-

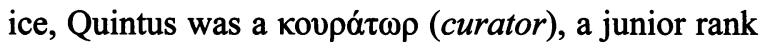
responsible for distributing the supplies issued by the summus curator from central stores to individual cavalry troops in a part-mounted auxiliary regiments (e.g., FINK 1971: 283). In other words the cohors I Augusta Cyrenaica was certainly a part-mounted or equitate unit at the time and, as such, was probably formed originally on this basis. The details of the second man honoured by the monument, Lucius Valerius Valens, are given in smaller lettering, suggesting he died at a later date than Quintus. Valens was then a cavalryman, and had completed 13 years in the auxilia. What is more, as he had the tria nomina of a Roman citizen, he represents one of those rare instances of a citizen who chose military service in the nominally peregrine auxilia rather than the legions - and at that, service as an ordinary soldier and not as was more often the case, as one of the unit's principales, its junior officers (cf. SPEIDEL, M.P. 1970: 142-153 (= SPEIDEL, M.P. 1984: 173-187); HOLDER 1980: 86-90; PFERDEHIRT 2002: 16).

That aside, it remains to note that the funerary monument of these two men was paid for by their wives, who are named as Marcia Aemilia Athenais and Artemisia, the tria nomina of the first indicating that she also was a Roman citizen. Now, until some time during the reign of Severus (AD 193-211), serving soldiers below the rank of centurion were prohibited from contracting a legal marriage, and any such union entered into by a man before he entered the army was legally voided on enlistment for the duration of his military service ( $c f$. CAMPBELL 1978: 153-166; the relevant evidence has been recently and thoroughly reviewed in Phang 2001, Part One). The reason for this prohibition was at least partly so that the state could circumvent any form of responsibility for the wife and children of serving soldiers both while these men were alive and after their death, but it also served to maintain 'soldiery' spirit and ethos (Phang 2001: 346-368, 372-377, and 381-383). Now, it is clear that before the Severan reform, individual Roman regimental commanders turned a blind eye towards the private lives of the ordinary soldiers they were responsible for (VAN DRIEL-MURRAY 1995). In this case, however, as one of the men commemorated - most likely Valens - was married to a Roman citizen, Marcia Aemilia Athenais, we might incline to the view that this was an entirely legal marriage, and that the text dates to the time of Severus' negation of the prohibition that serving soldiers could not marry. In its own way, then, we might find here further confirmation that the inscription belongs to a time before the Constitutio Antoniniana of AD 212.

The second funerary monument from Ancyra confirms the equitate nature of the cohors I Augusta Cyrenaica. This text (Bosch 1967: 138, no. $115=$ French 2003: 164, no. 55; also ByRne \& LABARRE 2006: 48), which gives the title of the unit as ' $\chi(\omega \dot{\rho} \tau \eta)$

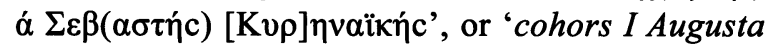
Cyrenaica', records the death of one Sergianus Longus, a 25-years old cavalryman who died after seven years service. His citizenship at the time of his death is unclear. It could be that he was a peregrine who had adopted or was registered on enlistment with two Romanised names, combining a gentile name and cognomen. This practice is known of from the Hadrianic period even though it was in direct contravention of a law made by Claudius that peregrini were not to adopt Roman gentilicia (MANN 2002: 227 with 230). If so, we might suggest a date for Longus' enlistment before the issuing of the Constitutio Antoniniana in AD 212. Alternatively, he may have been a Roman citizen who chose to serve in the auxilia, in which case the omission of his praenomen suggests a date after the mid- $2^{\text {nd }}$ century, when praenomina began more frequently to be left off funerary inscriptions (SALWAY 1994: 131). Such speculation aside, it needs to be added that the monument itself lacks the name of any dedicator; a feature that is generally believed to indicate the monument was erected by the serving comrades of the deceased. 
A third Greek-language funerary text from Ancyra needs to be noted as it might also honour a member of the unit. It memorialises a cavalryman named Proculus, a native of Iconium (Konya), and was erected by one Novianus - who describes himself as 'brother' of the deceased - and Epiktesis, the foster-daughter of Proculus (Bosch 1967: 138, no. 115 = FRENCH 2003: 164, no. 55). It should likewise belong to the period before the issuing of the Constitutio Antoniniana as it gives a single name and origo only for the dead man. Although the text does not name Proculus' regiment, his place of origin suggests he may have been a member of the cohors I Augusta Cyrenaica as the unit was present there at some point in its career. This is shown by a now-lost Greek-language altar from Iconium that bore the image of a cavalryman and the wording ' $\Sigma \pi i p \eta \varsigma \alpha$ ' Kvpvaïn [c]' for cohors I Cyrenaica (RAMSAY \& RAMSAY 1928: 183-184), but which apparently provided no clear indication as to its date.

Whatever unit Proculus belonged to, the existence of two funerary monuments at Ancyra memorialising three soldiers of the cohors I Augusta Cyrenaica and with formulae appropriate for a late $2^{\text {nd }}$ or very early $3^{\text {rd }}$ century date suggest that at least a part of the unit was present in the Galatian capital at that time. True, it could be that these men were on detached duty serving as singulares for the provincial governor, for these officials were regularly provided with such bodyguards and escorts from the units under their command ( $c f$. SPEIDEL, M.P. 1978: 7). On the other hand, if that were the case, then we might rightly expect them to be described as singulares on their funerary texts, as with that from Pisidian Antioch. Consider for example another funerary inscription from Ancyra set up by one Julius Timotheos, who expressly stated in the text that he was a ' $\sigma l v \gamma \lambda \alpha \rho \imath o \varsigma ~ \imath \pi \pi \varepsilon v \varsigma$ ', that is, an 'eques singularis', but without naming his parent unit (Bosch 1967: 412 , no. 367) - which could well have been the cohors I Augusta Cyrenaica.

All in all, it seems highly likely that the cohors I Augusta Cyrenaica was formally based in or close to Ancyra at the time when at least three of its members died there. If so, however, then Ancyra was not the only place in Galatia where the members of the unit were based during the late $2^{\text {nd }}$ and early $3^{\text {rd }}$ century AD. A recently discovered and as yet unpublished altar inscribed in Latin that was found and is now displayed at Gordion, $100 \mathrm{~km}$ west of Ancyra, demonstrates this. The primary text on the altar is a dedication to Victory on behalf of Marcus Aurelius, but a secondary text inscribed on a purposely smoothed-off part of the altar names the cohors prima Cyrenaica (sic) with the additional cognomen of Antoniniana. This sup- plementary title first appeared in ca AD 212, when Caracalla (AD 211-217) awarded it to those units that supported him following the assassination of Geta, his brother and imperial colleague; then, in AD 216, the same emperor made a repeat of the award to those regiments that served with him in the first year of his Parthian War (FITz 1983: 82-83). The title was revived as a military distinction in AD 218, when Caracalla's eventual successor, Elagabalus (AD 218-222) granted it to the units that helped suppress revolts against him when he was declared emperor (ibid.: 88-89). In other words, the title was not current any earlier or later than ca AD 212-218.

As it is, the new Gordion inscription lacks the name of any commanding officer, which would imply that only a part of the cohors I Augusta Cyrenaica was there at the time the second text was added to the altar. Thus, the text was probably commissioned by a group of men serving there on detached duty as stationarii, in effect as local policemen (Austin \& RANKov 1995: 195-204). Use of auxiliary men in this way was a common feature in Rome's provinces, and became increasingly so under the Severans and later, although the practice had certainly existed from at least as early as the time of Trajan ( $c f$. Pliny Epistulae 10. 77 and 78). Gordion had, in fact, been the location of a military base in the $1^{\text {st }}$ and early $2^{\text {nd }}$ century $A D$, at which time it probably took the Celticised name Vindia (BENNETT \& GolDMAN 2007), and although Vindia is listed as a polis in Ptolemy's Geographia, it is indeed named as a statio or military-supervised staging post in the $A n$ tonine Itinerary (FRENCH 1978: 294; BELKE \& RESTLE 1984: 171). More to the point, it has been argued from a military pendant and the 'military'-type footwear found in $3^{\text {rd }}$ century graves at Gordion that a Roman army unit or part thereof was again deployed at the place at this later date (GoldMAN 2001: 21 for the pendant; an exact parallel is known from [presumably] $3^{\text {rd }}$ century levels at Dura Europos, JAMES 2004: fig. 43, no. 307; also GolDMAN 2007: esp. 314-315). As such, then, the new inscription helps confirm the identification of Gordion/ Vindia as a statio under military supervision.

The Gordion inscription is the last certain reference to the cohors I Augusta Cyrenaica. Unless, that is, it is the same unit as the otherwise anonymous cohors [---] Maximinianae named on an honorary inscription from Basriköy, $30 \mathrm{~km}$ east of Gordion, which is intrinsically dated to AD 235 (CIL 3.6770= MitCHELL 1982: 188-189, no. 225). Either way, it has been shown above that all the literary and epigraphic records reporting the presence of the cohors I Augusta Cyrenaica reveal how it served in either Galatia-Cappadocia or Galatia alone from (probably) at least the time of Hadrian until the 
mid- $3^{\text {rd }}$ century. Thus it needs to be noted for the sake of completeness that those tiles from the Roman fort at Tihau in the Roman province of Dacia thought to have been stamped CI CY (CIL 3.8074, 13) in reference to the unit (e.g., Spaul 2000: 386) are now generally accepted as having been misread for CI CF, and so refer to the cohors I Cannanefatium (e.g., Petolescu 2002: 95, n. 13; $c f$. BENNETT 2006b: 282).

\section{The cohors II Augusta Cyrenaica}

The cohors II Augusta Cyrenaica was certainly in existence by $\mathrm{AD} 74$ for it is listed as such on a diploma recording the garrison of Germania in that year (CIL 16.20). As we have already seen, a reference to a unit in a diploma could well mean that the unit had by then already been in existence for some 25 years, which in this case could indicate it was formed sometime before $\operatorname{AD~49,~the~emphasis~on~'could'~being~for~reasons~}$ already stated. Whatever the case might be here, the cohors II Augusta Cyrenaica is then listed among the garrison of Germania Superior on diplomata of AD 90, where it appears without the title Augusta (CIL 16.36, with RMD 333, and ECK \& PANGERL 2004: 259-262), but with this on diplomata issued in $\mathrm{AD} 116$ and in $\mathrm{AD}$ 134 (CIL 16.62 and 80). Thus, whatever the date of its initial creation, this Cyrenaean regiment seems to have remained a permanent part of the German garrison from at least the time of Vespasian to that of Hadrian.

It may have been stationed for a while at Nida (Heddernheim), as one of its members, Atilius Tertius, set up an altar there to Dolichenus (CIL 13.7342). Once again we have a man whose nomenclature presents problems in identifying his exact citizenship status, but more to the point, Tertius describes himself in the text as 'ex coh(orte) II Aug(usta) C(yrenaica)'. This could mean that at the time the altar was erected, he was a veteran, in which case this altar may well have no bearing on where the unit was stationed at the time. Even so, a late $2^{\text {nd }}$ century or early $3^{\text {rd }}$ century date seems likely for this inscription as this was a period when Dolichenus became especially popular amongst Roman soldiers. At some point in its life, however, the cohors II Augusta Cyrenaica was certainly at Heidelberg-Neuenheim. Such is shown by several tiles from there that were made by the unit and so indicating building activity by the cohort at this place (CIL 13.12431). Indeed, it may also have been involved in some form of building activity at Butzbach as well, as another tile of the unit is reported from there (CIL 13.12432). More conclusively, however, the members of the turma or cavalry troop of the cohors II Augusta Cyrenaica (sic) restored a mithraeum at Heidelberg while under the command of a decurion named Aurelius (CIL 13.6407), thus confirming that the regiment, like the cohors I Augusta Cyrenaica, was a part-mounted unit. Moreover, as with Dolichenus, Mithras was a deity popular amongst the Roman army from the Severan period onwards, and so the fact that the unit was restoring an existing temple to this god suggests this work took place after the beginning of the $3^{\text {rd }}$ century. Furthermore, as we have already seen, the nomen Aurelius was one commonly taken by those men (including auxiliary soldiers) enfranchised by the Constitutio Antoniniana of AD 212. As such this would help confirm a $3^{\text {rd }}$ century date for this text, but either way, this and the immediately preceding text would seem to be the last dateable references to the unit's existence.

\section{The cohors III Augusta Cyrenaica sagittaria}

The existence of a cohors III Augusta Cyrenaica sagittaria has long been known of from inscriptions naming four of its commanders. What is probably the earliest of these texts records the highly unusual career of Caius Vibius Quartus, a worthy of Thessalonica in Macedonia $($ CIL 3.647 $=$ CIL 3.7337 = ILS 2538 = AE 2003.1606; also DEVIJVER 1977: 869-870, and DEVIJVER 1987: 1773, with AE 2003.1591 = RIZAKIs 2003). He began his military service as miles, an ordinary legionary, in the legio V Macedonica, and was then promoted to decurion in command of a cavalry turma in the ala Scubulorum, following this with a quasi-civil post as strategos of a part of Thrace. Then came his astonishing appointment as praefectus of the cohors III Cyrenaica (sic), after which Quartus was made a tribune in the legio II Augusta, then praefectus of an ala, perhaps an ala Gallorum, and finally praefectus of the classis Augusta Alexandria, the Roman fleet stationed at Egypt's capital. It has been argued that this sequence of appointments, and especially Quartus' promotion from the ranks to field officer, would best fit a date under Claudius, when the military career structure was not so formalised as it became under later emperors (RIzAKIs 2003: 547). That aside, it needs to be noted that M.A. SPEIDEL (2007: 81) has mistakenly taken these purely honorific texts as indicating that the unit had served in Moesia.

The second of these four inscriptions is from Forum Clodii in Etruria, a place situated some $40 \mathrm{~km}$ north-west of Rome on the Via Clodia, and names a Publilius Memorialis, a native of that place (CIL $11.7554=$ ILS $9195=$ AE 1896.10 and 1952.34; $c f$. DeVIJVER 1977: 682-683, P 111). He began his equestrian career as praefectus of the cohors III Cyrenaica sagittariorum (sic), the additional epithet indicating 
the unit had a complement of archers. He then went on to serve his tribunate with the legio $X$ Fretensis, a legion stationed in Syria from at least 4 BC (DABRowA 2000: 318), from which M.A. SPEIDEL (2007: 81) has supposed that this points to the cohors III Augusta Cyrenaica having been in the same province. This is hardly credible as in general an equestrian did not follow his initial auxiliary prefecture with a posting to a legion in the same military command. Either way, nothing in the text gives any clear indication as to its date, although there are good reasons for believing Memorialis' career belongs to the Flavian period and early Trajanic periods, not the least because this man came from Italy. After the reign of Hadrian, most auxiliary praefecti came from the provinces.

Assuming the preceding text to be Flavian in date, the next dated reference to the cohors III Augusta Cyrenaica (sic) is to be found on the already mentioned and unpublished diploma for Galatia-Cappadocia issued on 29-iii-101 (Pferdehirt 2004: 18, n. 1). Then again, as we have also seen, Arrianus' Ektaxis kat'Alanon of ca AD 135 mentions a unit of Cyrenaeans among the Cappadocian regiments that he commanded, but more to the point, in one place his text supplies the decisive information that this Cyrenaean unit contained a complement of foot-archers (Arrian Ektaxis 18). This shows that the Cappadocian unit of Cyrenaeans was the cohors III Augusta Cyrenaica, the only one known to have included archery specialists.

The third inscription recording the existence of the cohors III Cyrenaica (sic) comes from Almasu de Mijloc, in Roman Dacia (AE 1971.367; cf. DeVIJVER 1977, 912-913, Inc. 40). It reports the career of a man whose name is now lost and whose cursus honorum is given with his military commands listed above his civil offices, these having been held before or in parallel with his successive military appointments. One of his civil offices, however, as civil decurion of his community, was held during the joint reign of Marcus Aurelius and Lucius Verus, and so he began his military career as praefectus of the cohors III (Augusta) Cyrenaica during or after the period AD 161-169. What is more certain is that his subsequent military posting, as legionary tribunate in the legio XII Fulminata, was before AD 175: the legion is named thus on the inscription and without the honorary titles certa constans ('dependable and constant') awarded to it in that year for loyalty during the revolt of Avidius Cassius (RE XII, col. 1708).

The last known commander of the cohors III Augusta Cyrenaica was C.Aelius Domitianus Gaurus. His career is reported on an inscription from Pozzuoli (Puteoli) in Italy (AE 1888.125; $c f$. DeVIJVER 1976:
59-60, A 31), and it reveals that he began his civil and military career under Marcus Aurelius alone, so AD 169-177, his first command being of the III Augusta Cyrenaica (sic). He was then appointed as a tribune with the legio XII Fulminata certa constans, around or shortly after $A D 175$, when it received this award for its loyalty.

\section{Discussion}

The evidence detailed above, scant though it is, allows us to make at least some tentative conclusions about the origins and deployment of the cohortes Augustae Cyrenaicae. For one, the use of the name Augusta in their shared title and the way that they are numbered in sequence suggest that they were formed in quick succession during the lifetime of Augustus himself, as was likely to be the case with the only other sequentially-numbered units that used this imperial name, the three Thracian cohortes. As it is, some support for the premise that the Cyrenaean units were formed under Augustus is given by the way that the first and third cohortes Augustae Cyrenaicae apparently spent their entire existence in the provinces of Galatia and Cappadocia (contra M.A. SPEIDEL 2007: 81, with regard to the second). This is a strong pointer to their having been deployed to one or other these provinces from a date close to when these commands were instituted, $25 \mathrm{BC}$ for Galatia and AD 17 for Cappadocia. In fact we might speculate even further, and propose that if these regiments were initially raised by Quirinus for his campaign against the Marmaridae in $14 \mathrm{BC}$, then he might well have asked for their transfer to Galatia in connection with his albeit much later war with the Homonadeis of Isuaria between $6 \mathrm{BC}$ and AD 4. Alternatively, it could be that they were transferred directly to Cappadocia when that province was formed in $\mathrm{AD}$ 17. Until the Neronian period, the province was without a legion, and so before that time it was garrisoned entirely by auxilia. As M.A. SPEIDEL (2007: 84) has commented, "the early history of the exercitus Cappadocicus ... remains poorly documented", although a garrison of at least 10 quingenary units, equal to the number of soldiers in a regular legion, or even more, can safely be assumed ( $c f$. BENNETT 2006a: 78-83). Consider for example the data from two other provinces without legions that also faced onto hostile territory: Mauretania Tingitana, a province smaller than Cappadocia, and Mauretania Caesariensis, somewhat larger, were each garrisoned by some 15 auxiliary units in the Hadrianic period ( $c f$. HoLDER 2003: 145).

Concerning the precise nature of these units, it is to be noted that at least two of them are recorded 
as being equitate at some point in their existence, and they were quite probably so from the very beginning. This assertion might initially surprise some of those familiar with the mountainous interior of Cyrenaica, yet in the pre-Roman times, the Cyrenaeans were famous for their war-chariots (e.g., Arrian Tactika 19), while in the Augustan period, the quality of their horses was singled out as one of the reasons for Cyrene's prosperity (Strabo Geographia 17.3.21). What will be perhaps less surprising, on the other hand, is that one of these three units, the cohors III Augusta Cyrenaica, was a unit of sagittarii, that is, with a complement of archery specialists.

Given the very limited evidence at our disposal, nothing can be said with regard to the matter of whether or not any of these Cyrenaean regiments continued to recruit from their 'home' territory after being deployed in Europe and Asia Minor, although it might be suspected that the cohors III Augustae Cyrenaicae continued to recruit its archers from 'home'. The fact is that we rely principally on diplomata and the funerary memorials of deceased members of Rome's auxilia for such information, and yet remarkably few examples of either type of document exist today for the many thousands of men who must have served in these regiments. Consider for example the epigraphic record left by the ala I Ulpia Contariorum milliaria, a unit of ostensibly 1,000 men but more probably with 720 regularly on its books (KEPPIE 1996: 391), which was stationed in Pannonia Superior from at least AD 112-154. All auxiliary cavalrymen were better paid than was the case with the auxiliary infantry (e.g., M.A. SPEIDEL 1992: 93, tab. 3, with 99) and so it might be expected that a regiment like this would leave a reasonably large epigraphic footprint imprint for its former existence. However, there are a scant two diplomata and a mere four detailed funerary texts for the unit in question, a minimal number for the 720 men who served with the regiment in any one year, and a miniscule amount of the more than double that figure who must have passed through its ranks in the 42 years of its known existence. When we take into account that the ala I Ulpia Contariorum milliaria is one of the better-represented auxiliary units with regard to the epigraphic record of its soldiers, it should come as no surprise that we have so few records for the three cohortes Augustae Cyrenaicae - and none at all revealing what proportion of its members were in fact Cyrenaean in origin.

By contrast with the lower ranks, the much betterpaid commanders of Rome's auxilia are relatively well represented in the epigraphic record. However, we know of only five praefecti for the three cohortes $\mathrm{Au}$ - gustae Cyremaicae - and four of these were former commanders of the same cohort, the cohors III Augusta Cyrenaica. Moreover, only one of them appears to have risen to any great level of authority in the Roman career structure. This could be because several of the relevant inscriptions are honorific texts that were set up before the person reached the apogee of their career or because the inscription is incomplete. For example, in the case of the single man known to have risen to a high rank in the equestrian career, C.Vibius Quartus, former praefectus of the cohors III Augusta Cyrenaica, while one inscription relating to him ends with his prefecture of an ala (CIL $3.647=$ CIL $3.7337=$ AE 2003.1606), another reveals he then went on to command the classis Augusta Alexandria (AE 2003.1591). All in all, however, the impression is that most of the men who commanded these Cyrenaean units conformed to the prevailing convention, which saw military service as a necessary step following on from and / or preceding public office in their own community (e.g., BIRLEY 1988: esp. 148-150). That said, there is at least a possibility that such posts may have been held in parallel, as it were, in the sense that it might have been that certain civil offices were held between the various levels of the equestrian military career.

\section{Acknowledgements}

This article stems from a long-term research project into the deployment of auxilia in Galatia and Cappadocia, supported by my departmental colleagues and by Bilkent University. I offer it to John Spaul as a tribute to the two major works of reference he has provided for scholars of the Roman auxilia, namely his Ala 2 (Farnborough 1994) and Cohorts 2 (Oxford 2000). Without these 'quarries', the necessary 'ores' for further research would be much harder to obtain and 'refine'. I thank Jacques Morin and Asuman Coşkun Abuagla for their assistance with the Greek and Latin language texts, and I also wish to acknowledge the invaluable assistance provided during the preparation of this article by the 24/7 EpigraphikDatenbank Clauss/Slaby (http://www.manfredclauss. $\mathrm{de} /)^{\prime}$, and also by the librarians of the British Institute at Ankara and the German Archaeological Institute in Istanbul. I also gratefully acknowledge the helpful comments of Michael A. Speidel and especially the remarks of an anonymous reviewer, whose critical observations have significantly enhanced the topics discussed here. I hope that this article meets with the approval of all those named above, while at the same time stressing that any errors herein are entirely of my own making. 


\section{Abbreviations}

AE: L'année épigraphique

CIL: Corpus Inscriptionum Latinarum

RE: Real-Encyclopädie der klassischen Altertumswissenschaft

RMD: Roman Military Diplomas

SEG: Supplementum epigraphicum Graecum

\section{Bibliography}

Austin, N.J.E. \& Rankov, B. 1995. Exploratio: Military and Political Intelligence in the Roman World from the Second Punic War to the Battle of Adrianople. Routledge, London.

Bechert. T. 1999. Die Provinzen des Römischen Reiches. Einführung und Überblick. Philipp von Zabern, Mainz.

Belke, K. \& Restle, L. 1984. Galatien und Lykaonien. Tabula Imperii Byzantini 4. Verlag der Österreichischen Akademie der Wissenschaften, Wien.

Bennett, J. 2006a. The origins and early history of the PonticCappadocian frontier. Anatolian Studies 56, 77-92.

Bennett, J. 2006b. The Cohors Equitata fort at Tihău-Cetate, Romania: the results of geophysical survey and other research. Journal of Roman Archaeology 19, 278-299.

Bennett, J. 2007. The Roman army in Lycia and Pamphylia. Adalya 10, 131-153.

Bennett, J. forthcoming. Auxiliary Deployment during Trajan's Parthian War: some neglected evidence from Asia Minor. Collections Latomus.

Bennett, J. \& Goldman, A.L. 2007. Roman military occupation at Yassihöyük (Gordion), Ankara Province, Turkey. Antiquity 81 (314). (http://antiquity.ac.uk/ProjGall/bennett/index.html).

Birley, E.B. 1966. Alae and Cohortes Milliariae. In: Corolla Memoriae Erich Swoboda dedicata. Römische Forschungen in Niederösterreich 5. Hermann Böhlaus, Graz-Köln, pp. 54-67 (= Birley 1988: 349-364).

Birley, E.B. 1988. The Roman Army: Papers 1929-1986. Mavors Roman Army Researches 4. J.C. Gieben, Amsterdam.

Bosch, E. 1967. Quellen zur Geschichte der Stadt Ankara im Altertum. Türk Tarih Kurumu Basimevi, Ankara.

Brunt, P.A. 1974. Conscription and Volunteering in the Roman Imperial Army. Scripta Classica Israelica 1, 90-115 (= Brunt 1990, 188-214).

Brunt, P.A., 1990: Roman Imperial Themes. Clarendon Press, Oxford.

Byrne, M.A. \& Labarre, G. 2006. Nouvelles inscriptions d'Antioche de Pisidie, d'après les note-books de W.M. Ramsay. Inschriften Griechischer Städte aus Kleinasien 67. Habelt, Bonn.
Campbell, J.B. 1978. The Marriage of Soldiers under the Empire. Journal of Roman Studies 68, 153-166.

Cheesman, G.L. 1914. The Auxilia of the Roman Imperial Army. Oxford University Press, Oxford.

Dabrowa, E. 2000. Legio X Fretensis. In: Le Bohec, Y. \& Wolff, C. (eds.), Les Légions de Rome sous le Haut-Empire 1. Boccard, Paris, pp. 317-325.

Daris, S. 2000. Legio XXII Deiotariana. In: Le Bohec, Y. \& Wolff, C. (eds.), Les Légions de Rome sous le Haut-Empire 1. Boccard, Paris, pp. 260-308.

Devijver, H. 1973. Some observations on Greek terminology for the Militiae Equestres in the literary, epigraphical and papyrological Sources. In: Zetesis. Album amicorum door vrienden en collega's aangeboden aan prof. dr. E. de Strycker. Amsterdam, pp. 549-565 (= Devijver 1989: 56-72).

Devijver, H. 1976: Prosopographia Militiarum Equestrium quae fuerunt ab Augusto ad Gallienum, 1: Litterae A-I. Cultura Press, Wetteren.

Devijver, H. 1977. Prosopographia Militiarum Equestrium quae fuerunt ab Augusto ad Gallienum, I1: Litterae L-V. Cultura Press, Wetteren.

Devijver, H. 1987. Prosopographia Militiarum Equestrium quae fuerunt ab Augusto ad Gallienum, IV: Supplementum I. Cultura Press, Wetteren.

Devijver, H. 1989. The Equestrian Officers of the Roman Imperial Army I. Mavors Roman Army Researches 6. Brill Academic Publishers, Amsterdam.

DeVoto, J.G. 1993. Flavius Arrianus: Tactical Handbook and the Expedition Against the Alans. Ares, Chicago.

Eck, W. \& Pangerl, A. 2004. Neue Diplome für die Heere von Germania Superior und Germania Inferior. Zeitschrift für Papyrologie und Epigraphik 148, 259-268.

Fink, R.O. 1971. Roman Military Records on Papyrus. Case Western Reserve University, Cleveland, Ohio.

Fitz, J. 1972. Les Syriens à Intercissa. Collection Latomus 122. Universitaire de Belgique, Brussels.

Fitz, J. 1983. Honorific Titles of Roman Military Units in the $3^{\text {rd }}$ Century. Habelt, Bonn.

French, D.H. 1978. Roman roads in Central Anatolia. In: Akurgal, E. (ed.), Proceedings of the $X^{\text {th }}$ International Congress of Classical Archaeology: Ankara-Izmir 23-30/IX/1973, I. Türk Tarih Kurumu, Ankara, pp. 293-294.

French, D.H. 2003. Inscriptions of Ankara. The Museum of Anatolian Civilizations, Ankara.

Goldman, A.L. 2001. A Roman town cemetery at Gordion, Turkey. Expedition 43 (2), 9-22.

Goldman, A.L. 2007. The Roman-period cemeteries at Gordion in Galatia. Journal of Roman Archaeology 20, 297-320. 
Gómez-Pantoja, J. 2000. Legio IIII Macedonica. In: Le Bohec, Y. \& Wolff, C. (eds.), Les Légions de Rome sous le Haut-Empire 1. Boccard, Paris, pp. 105-117.

Gruen, E.S. 1996. The expansion of the empire under Augustus. In: Bowman, A.K., Champlin, E. \& Lintott, A. (eds.), The Cambridge Ancient History, Volume X: The Augustan Empire, $43 B C-A D$ 69. Cambridge University Press, Cambridge, pp. $147-198$.

Holder, P. 1980. Studies in the Auxilia from Augustus to Trajan. British Archaeological Reports International Series 70. BAR, Oxford.

Holder, P. 1998. Auxiliary Units entitled 'Aelia'. Zeitschrift für Papyrologie und Epigraphik 122, 253-262.

Holder, P. 2003. Auxiliary deployment in the reign of Hadrian. In: Wilkes, J.J. (ed.), Documenting the Roman Army: Essays in Honour of Margaret Roxan. Institute of Classical Studies, London, pp. 101-145.

James, S. 2004. Excavations at Dura-Europos, Final Report Volume VII: The Arms and Armour, and Other Military Equipment. British Museum Press, London.

Kennedy, D.L. 1977. The ala I and cohors I Britannica. Britannia 8, 249-255.

Kennedy, D.L. 1983. Milliary cohorts: the evidence of Josephus BJ II.4.2 (67) and of epigraphy. Zeitschrift für Papyrologie und Epigraphik 50, 253-263.

Keppie, L.F.J. 1984. The Making of the Legions. Batsford, London.

Keppie, L.F.J. 1996. The Army and the Navy. In: Bowman, A.K., Champlin, E. \& Lintott, A. (eds.), The Cambridge Ancient History, Volume X: The Augustan Empire, 43 BC-AD 69. Cambridge University Press, Cambridge, pp. 371-296.

Levick, B. 1967. Roman Colonies in Southern Asia Minor. Oxford University Press, Oxford.

Mann, J.C. 2002. Name forms of recipients of diplomas. Zeitschrift für Papyrologie und Epigraphik 139, 227-234.

Mitchell, S. (ed.) 1982. RECAM II: Regional Epigraphic Catalogues of Asia Minor: The Ankara District, the Inscriptions of North Galatia. British Archaeological Reports International Series 135. British Institute of Archaeology Monograph 4. BAR, Oxford.

Mitchell, S. 1993. Anatolia: Land, Men and Gods in Asia Minor 1I: the Rise of the Church. Oxford University Press, Oxford.

Petolescu, C.C. 2002. Auxilia Daciae. Ars Docendi, Bucharest.

Phang, S.E. 2001. The Marriage of Roman Soldiers (13 BC-AD 235). Brill, Leiden.

Pferdehirt, B. 2002. Die Rolle des Militärs für den sozialen Aufstieg in der römischen Kaiserzeit. Römisch-Germanisches Zentralmuseum Monograph M-49. Habelt, Bonn.
Pferdehirt, B. 2004. Römische Militärdiplome und Entlassungsurkunden in der Sammlung des Römisch-Germanischen Zentralmuseums. Römisch-Germanisches Zentralmuseum Kataloge vor- und frühgeschichtlicher Altertümer K-37. Habelt, Bonn

Ramsay, W.M. \& Ramsay, A.M. 1928. Roman Garrisons and Soldiers in Asia Minor. Journal of Roman Studies 18, 181-190.

Rizakis, A. 2003. La carrière équestre de C. Vibius Quartus. Mélanges de l'école française de Rome 115 (2), 535-548.

Salway, B. 1994. What's in a name? A survey of Roman onomastic practice from c. 700 B.C. to A.D. 700. Journal of Roman Studies 84, 124-145.

Southern, P. 1989. The Numeri of the Roman imperial army Britannia 20, 81-140.

Spaul, J. 1994. Ala 2. Nectoreta Press, Farnborough.

Spaul, J. 2000. Cohors 2. Oxbow, Oxford.

Speidel, M.A. 1992. Roman army pay-scales. Journal of Roman Studies 82, 87-106.

Speidel, M.A. 2007. The development of the Roman forces in northeastern Anatolia. New evidence for the history of the exercitus Cappadocicus. In: Lewin, A. (ed.), The Late Roman Army in the Near East from Diocletian to the Arab Conquest. Oxbow, Oxford, pp. 73-90.

Speidel, M.P. 1970. The Captor of Decebalus: a new inscription from Philippi, Journal of Roman Studies 60, 142-153 (= Speidel 1984: 173-187).

Speidel, M.P. 1976. Citizen cohorts in the Roman imperial army: new data on the cohorts Apula, Campana, and III Campestris. Transactions of the American Philological Association 106, 339-348 (= Speidel 1984: 91-100)

Speidel, M.P. 1978. Guards of the Roman Armies: An Essay on the Singulares of the Provinces. Antiquitas Reihe 1, Band 28. Habelt, Bonn.

Speidel, M.P. 1982-1983. The Roman army in Judaea under the procurators. Ancient Society 13/14, 233-240 (= Speidel, M.P. 1992: 224-232)

Speidel, M.P. 1984. Roman Army Studies I. Mavors Roman Army Researches 1. Gieben, Amsterdam.

Speidel, M.P., 1992. Roman Army Studies II. Mavors Roman Army Researches 8. Steiner, Stuttgart.

Van Driel-Murray, C. 1995. Gender in Question. In: Rush, P. (ed.) Theoretical Roman Archaeology: $2^{\text {nd }}$ Conference Proceedings Oxbow, Oxford, pp. 3-21. 